Volume: 6, Issue: 3/September 2021

\title{
Rethinking Education Leadership through \\ Self-Reflection: Examining the TURNS Model
}

\author{
Vuyisile Msila
}

University of South Africa, South Africa

\begin{tabular}{|c|c|}
\hline Abstract & Article Info \\
\hline $\begin{array}{l}\text { With the policy windows open for decolonial practices, } \\
\text { educational leaders in Africa have much to ponder on as they } \\
\text { examine and transform their leadership practices to suit the } \\
\text { current climates. All progressive leaders seek to lead } \\
\text { institutions where they could motivate followers, enhance }\end{array}$ & $\begin{array}{r}\text { Article History: } \\
\text { Received } \\
\text { September 9, } 2020 \\
\text { Accepted: } \\
\text { May 5, } 2021\end{array}$ \\
\hline $\begin{array}{l}\text { performance as they utilise relevant leadership qualities. } \\
\text { Conscientious leaders in Africa would be eager to know what } \\
\text { it means to combine Western epistemology and indigenous } \\
\text { knowledge to achieve the institution's goals. Arguably, } \\
\text { today's institutions require leaders who will be able to study } \\
\text { their contexts and utilise leadership strategies for } \\
\text { effectiveness. }\end{array}$ & $\begin{array}{r}\text { Keywords: } \\
\text { Attuned leadership, } \\
\text { Decolonisation, } \\
\text { Ecologies of knowledge, } \\
\text { Self-reflection, Social } \\
\text { Justice. }\end{array}$ \\
\hline
\end{tabular}

\section{Cited as:}

Msila, V. (2021). Rethinking education leadership through selfreflection: Examining the TURNS model. Research in Educational Administration \& Leadership, 6(3), 662-690. DOI: 10.30828/real/2021.3.5 


\section{Introduction}

The new generation of African leaders face a number of challenges, not least the overall substandard, poor and malignant nature of leadership (Afegbua \& Adejuwon, 2012; Naidoo, 2019; USBED, 2018) and the inability to confront its own leadership weaknesses (Wafawarova, 2015), affecting the search for (new) Afrocentric leadership identities in institutions. The need for leadership in Africa to evolve and look inwardly as well as outwardly calls for a critical examination of the practice of leadership. Igue (2020) points out that new leaders in Africa need to be capable of facing challenges such as fragmentation of the region, history and knowledge, promotion of human rights and democracy. This article, therefore, underscores the need to question the idea of leadership in African institutions of education. It examines two central issues: on the one hand, it explores why effective leaders need continuous self-reflection whilst, on the other, it examines the inclusion of non-Western knowledge in a time of evolving organisational cultures.

It is important to bear in mind that leadership in Africa is not homogenous. Like elsewhere, leadership is complex and is influenced by several factors, including contexts and values that define such settings (Hallinger, 2018; Murphy et al. 2016). All diligent leaders seek to inspire others as they lead with meaningful values. Effective leaders will learn from a number of factors such as personal experiences, as well as through their followers' experiences. In an age of decolonisation in the Global South, leaders would need to 'rethink' and find ways of enabling their organisations to be adaptable to new, innovative leadership approaches.

I use the term 'rethink' to refer to new ways of looking at leadership and use the TURNS model (see Fig 1), to demonstrate how 
leaders can employ self-reflection to enhance their strength for effective leadership. Rethinking underscores the role of the leaders in Africa to consciously utilise effective but marginalised indigenous epistemologies as well. New perspectives need to be developed to enhance leadership for diversity and social justice and this must start with the self-empowerment of the leaders themselves. The article examines how leaders can use models such as the TURNS (leadership empowerment) model to transform their organisations. The article starts with a brief literature review which reveals how colonialism skewed leadership practice in Africa as well as how leaders who aspire effectiveness should constantly search for practices that would help develop their organisations. Lorri Santamaria's (2014) seminal work Culturally Sustaining Leadership is used to explore ways of rethinking leadership utilising eclectic approaches.

The discussion begins by examining why leadership fails in Africa. African intellectuals over the years have highlighted the negative role of colonialism in this regard (Mazrui, 2002; Khoza, 2012; Okeke, 2018; Wa Thiong'o, 2007). This then compels the African societies in particular, to investigate what needs to be done to build effective organisations. The TURNS model is put forward as a viable model that can engender school leaders' self-reflection whilst it underscores values that would enhance social justice principles for effective leadership practices in Africa.

\section{How Leaders Fail African Institutions}

Leadership failures that mar organisations hinder effectiveness: Ngugi Wa Thiong'o (2007) attributes many of the leadership failures in Africa to "blacknisation of colonialism." In explicating this concept, Wa Thiong'o argues that colonisation stripped Africa of its cultural identity and left behind challenges that 
included corruption and bad leadership. As the colonisers forsook the colonies, they also left behind institutions and governments that were fraught with leadership anomalies (such as patriarchy, colonial hierarchy in institutions). The postcolonial African leaders have struggled, unable to shirk off the exclusive Western practices as they emulated the former colonial models of leadership.

There is a strong realisation that current leadership theories used in organisations reflect only Western ideas and marginalise indigenous worldviews (De Padua \& Rabbitskin, 2017). This calls for an ecology of which foregrounds diversity, multilingualism and recognition of varied identities. Leaders who marginalise and segregate within institutions are unlikely to succeed in steering efficient institutions that need diverse values that would be pivotal in igniting commitment. When talking about globalectics, Wa Thiong'o (2012) puts forward an ambitious theory where he argues that there should be interconnectedness as well as equality of parts. In African educational leadership, globalectics would mean the combination of Global South and Global North identities. Stewart and Warn (2016) point out that many indigenous leaders need to straddle between two worlds as they work across boundaries combining western strategies and indigenous knowledges to enhance their leadership practice.

The combination of Global South and Global North identities is an attempt to build a strong epistemic granary. Ali Mazrui (2000) argues that knowledge is critical and that Africa's poverty emanates from a weak knowledge base. Furthermore, Mazrui argues that it matters how people are predisposed epistemologically hence leaders with the necessary knowledge will be able to consciously lead successful institutions. The success of African (educational) institutions today arguably rests on having a wider knowlegde base as 
well as thinking and rethinking relevant strategies. Since the advent of decolonisation in educational institutions such as schools, scholars, policy makers and practitioners have talked about the rethinking of organisations that are supposed to decentre exclusive Eurocentric values as they bring marginalised African values to the centre to create an ecology of knowledges (Ndlovu-Gatsheni, 2018). This is an idea Ngugi Wa Thiong'o (1993) accentuates when he talks about moving the centre. Moving the centre is about emphasising cultural freedoms and social change and this implies liberating the restrictions imposed upon world cultures by imperialism. Furthermore, moving the centre is about the quest for social justice in society demonised by epistemic violence and marginalisation of African values. Colonisation has always had a negative influence on authentic leadership in Africa (Okeke, 2018). Yet even more important, Africa is attuned to leadership which enables leaders learn to unlearn destructive colonial leadership practices.

In 1961, Julius Nyerere pointed out that it is a deceptive halftruth to say that leaders are born not made for "there is no man living whose qualities cannot be improved and developed by training" (Nyerere, 1970, p.124). In the same vein, Reuel Khoza (2012), in his book Attuned Leadership, explains that leaders are not just born into their roles, they are made. Leaders need to constantly learn to improve their practice to gain strong followership. Most importantly, a leader who is not attuned to his followers soon becomes irrelevant and will fail. Values such as connectedness, compassion, empathy, integrity, humility, reasonableness and determination are key to attuned leadership (Khoza, 2012). Furthermore, according to Khoza, attuned leadership uses African humanism which encompasses reason and empathy and is the basis or yardstick for decolonised ethical leadership in Africa. 
Hence, understanding African cultures is critical in understanding the dynamics of all organisations. Culture encompasses values (Mbigi, 2005) and these would include Western, African and other values that are part of any African setting. An effective leader would then need to embrace eclectic approaches when decolonising (African educational) institutions that Ali Mazrui's thought encompasses above. The engagement of consciousness plays a critical role in understanding and learning to unlearn the traditional approaches encapsulated in many colonial approaches. All the ideals of decolonisation would hardly work without a meaningful engagement of the consciousness echoing Paulo Freire's conscientisation (1970). It refers to an in-depth understanding of the world and being able to identify the oppressive unjust practices. Progressive leaders who have been conscientised would follow values that are legitimated by liberated or politically conscious thinking. All this constitutes a process of legitimation which is pivotal in understanding African leadership (Wai, 1997).

School leaders may fail if they do not engage with conscious thinking of the necessary theories. The imperial school leadership theories that originated in the United States (Santamaria, 2016) and instituted cultural hegemony in the practice of educational leadership in Africa will need to be deconstructed in order to acommodate 'subaltern' theories (Saffari, 2016), a concept in critical theory which refers to the marginalised worldviews that are relevant to effective organisations. Conscious leaders in Africa will need to be empowered in order to gain the courage to look within themselves as they support innovative organisational cultures. To achieve that goal, the TURNS Model is put forward as viable approach to educational leadership in Africa. 


\section{The TURNS Model for Effective and Relevant Leadership}

In preparing future school leaders, programmes should be intent on emphasising certain elements in their training programmes. All potential leaders need a new face of leadership. In my studies, I have designed a model to uphold decolonial strategies and oppose epistemic violence in leadership programmes (Msila, 2008; Msila, 2015). The following cycle represents this model:

Figure 1.

The TURNS Model of Leadership (Msila, 2020)

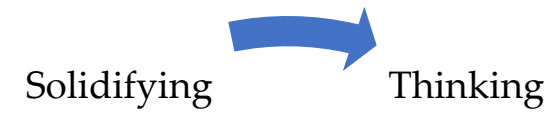

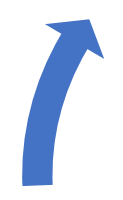

Nurturing

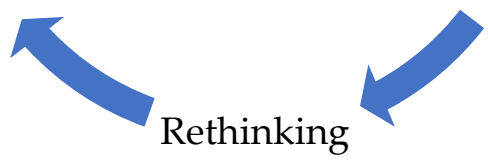

The above model is about transforming leadership and management, it is also about unlearning and learning new ways to enhance effective leadership. The concept TURNS comes from the five stages' first letters: 
Thinking

\section{Unthinking}

Rethinking

Nurturing and

Solidifying.

The philosopher Alvin Toffler (1970, p.367) points out that "the illiterate of the $21^{\text {st }}$ century will not be those who cannot read and write, but those who cannot learn, unlearn and relearn." The TURNS model (Figure 1) above accentuates Toffler's views. Accomplished leaders in Africa should be able to unlearn Wa Thiong'o's blacknisation and include the marginalised African practices.

The Thinking stage requires that leaders use the ecology of knowledges for effective leadership should begin with understanding their own practice through self-reflection. Many organisations fail because leaders do not understand both their organisations as well as themselves. Paulo Freire uses the term 'conscientisation' to refer to a process of making others conscious of the political and social conditions; it also refers to the action of being able to challenge inequalities in society. The TURNS model reflects this. When leaders learn to think, they become conscientised and use critical awareness in understanding their leadership roles. Thinking assists in understanding ways to deconstruct Western hegemony and epistemic violence. Thinking and also rethinking helps in the discovery or awareness of colonial hierarchies and demeaning models that dehumanise and seek alternative cultures and values.

Besides redressing Western hegemony, rethinking in leadership helps in the constant rebuilding of the organisation. Various writers have demonstrated that when leaders think their leadership practice, they are bound to improve their organisations immensely 
(Bennet, 2003; Davies, 2010) and similarly Vaughan (2013) states that if organisations are to grow the leaders must learn to think. Thinking ensures that members of an organisation never repeat the same mistakes. Organisations around the world struggle because of poor thinking. Davies (2010) posits that rethinking and thinking education leadership enables the organisation to move from improvement to transformation.

The Unthinking stage of the model refers to a stage where the leaders have to disengage with the past negative and internalised practices in leadership. In Toffler's philosophy it encompasses unlearning as people prepare to learn anew. This is also akin to the concept of "undoing" in psychology. During the undoing stage people shun destructive actions as they engage in new positive behaviours. Sigmund Freud introduced undoing as a defense mechanism (Laplanche \& Pontalis, 1973). A leader who unthinks also obliterates ingrained toxic forms of leadership such as absolute authority, patriarchal domination and egocentric leadership forms. Unthinking starts with the realisation that there is a need for mental change as leaders prepare for progressive organisations that thrive. After the Unthinking stage which is about the destruction of toxicity, rethinking comes in as a stage for rejuvenation and re-establishment of the institution.

Rethinking thinking in TURNS reminds leaders about the need to magnify critical knowledge that would enable them to unlearn what Macedo refers to as a false dichotomy between Western and indigenous knowledges. Macedo (1999, p. xv) posits:

It is only through the decolonisation of our minds, if not our hearts, that we can begin to develop the necessary political clarity to reject the enslavement of a colonial discourse... It is through the decolonisation of our minds and the development of political clarity that we cease to embrace the notion of 
Western versus indigenous knowledge, so as to begin to speak of human knowledge. It is only through the decolonisation of our hearts that we begin to humanise the meaning and usefulness of indigeneity.

True self-reflection will lead to these ideals as it engenders critical and broadmindedness in looking at leadership. Decolonial leaders should rethink all these notions to guide successful schools. In many instances school leaders are so obsessed about learner achievement and school effectiveness that they forget that this all begins with introspection and self-reflection. Rethinking leadership enables people to be conscious leaders who will know exactly how to cultivate decolonial practice in their leadership. Furthermore, conscious leadership is related to the Ubuntu worldview because conscious leaders emphasise the "we" rather than the "me" and they know their role is to create a culture of trust, care and influence (Vermey, 2014). Rethinking leadership ensures that leaders are made aware of unconscious leadership's pitfalls. Unconscious leadership means there is no reflection, hence the institution can easily become toxic. Unconscious leaders are unlikely to be bold and courageous in the face of change. Furthermore, the constantly changing society we live in needs conscious leaders who will not lose the organisation's vision. Dethmer et al. (n.d.) point out that conscious leadership offers an antidote to leadership by fear. Instead, conscious leadership transforms fear-based leadership to trust-based leadership. Healthy relationships, commitment, passion and energy are all qualities enhanced by conscious leadership. Conscious leaders communicate with integrity, lead with genuine approaches, and are not like unconscious leaders who usually are reactive and let their egos dominate.

Odora Hoppers and Richards (2012) write about ways of recentering marginalised epistemologies. The two authors argue for 
the moving of the centre, thus ensuring that the indigenous knowledge systems are brought forward. The TURNS model enables us to deeply examine the role of leadership in a decolonised environment. Odora Hoppers and Richards also discuss ways in which education institutions including universities need to redeem themselves from toxicity and how it can be a vehicle for transformation.

Untransformed leadership notions will not transform institutions and will not be positive agents to transform society. The process of rethinking thinking around leadership means that leaders will humanise their institutions and end epistemic violence as they instil values that would consider issues of diversity and social justice. African leaders need to magnify the vision of humanising workplaces and entrenching the qualities of solidarity, community, dependability and commitment explicated above under Ubuntu. When I talk about the need to rethink thinking, it is an attempt to search for new paradigms and new solutions. If leadership is to transform, it needs us to rethink the content. Newman (2012) also uses the concept of rethinking thinking as he contemplates paving the way for positive leadership. He argues that organisations can attain sustainable behavioural advantage if they help managers understand and improve how they think about what drives success or failure in their everyday lives.

Vaughan (2013) has also supported the idea of rethinking thinking when it comes to leaders. He highlights that how to think is more critical than what to think. His theory is important when one looks at alternative perspectives. Like Odora-Hoppers and Richards as well as Newman above, Peter Senge (1995) also highlights the role of rethinking leadership in sharpening the skills of leadership in learning organisations. Rethinking leadership starts with the commitment of 
the leader. Furthermore, Senge (1995) points out that there is no one who can force another person to learn, when learning involves profound changes it needs strong individual commitment in new attitudes and new beliefs.

Rethinking will be incomplete without the Nurturing stage which fosters the necessary values. Effective rethinking in African institutions leads to self- reflective leaders who use indigenous values encapsulated in African epistemologies. Among these values are those embodied in the Ubuntu worldview. Some of the values embraced by Ubuntu are humanness, solidarity, communalism and commitment. Ubuntu opposes negative competition as it promotes unified ways to focus on the vision. Leaders who use the Ubuntu worldview move towards decolonisation. Ubuntu is unique to Africa although elements of this worldview are found in Western philosophies such as servant leadership. This is a point made by Elonga Mboyo (2019) who avers that Ubuntu has similarity to Western colleagial models that utilise participative approaches.

These values need to be nurtured and nurturing leadership is about developing or enhancing one's leadership skills. Leaders need to work on their weaknesses as they strengthen the positive attributes. Effective leaders will develop others with leadership potential in the institution. Nurturing helps in increasing the institution's productivity. During the nurturing process, effective leaders develop a symbiotic and trusting relationship with the followers. When trust happens it leads to the leaders' influence which in turn will build personal growth pivotal in institutional success. It is at this stage that solidifying comes into the picture.

Solidifying stage can only happen when the other stages above have been accomplished. And it involves congealing values and 
culture developed in the initial stages of the TURNS model above. Solidifying refers to a process of the leaders' ultimate transformation and self-discovery. During this stage, leaders select their preferred ways of leading organisations. Without the process of self-reflection the solidifying stage will be unattainable or inadequate. The stages of Thinking, Unthinking and Rethinking form part of the self-reflection process and finalised when leaders establish effective values to lead their organisations. Msila (2020) states that leaders who consciously transform their practice are scrupulous leaders who have solidified their practice through the realisation of relevant qualities. Solidified leaders are professionally matured hence they have been able to nurture the necessary values leading to the embracement of progressive values.

Turning the institution's leadership in TURNS seek to attain the ultimate goal which means reinforcing certain qualities. Only leaders who are aware of their goals and vision can explore solidification. If they use Ubuntu as a philosophy, they should highlight the values to lead their institutions and solidify these, working with their teams.

Aspects of the TURNS model stages are reflected in several theories in Africa and the world. Below, I explore the implications of Khoza's (2012) and Santamaria's (2014) contentions on leadership and self-reflection for social justice.

\section{Self-Reflection and Decolonisation of Leadership for Social Justice}

Among the major elements addressed by the TURNS Model is the idea of social justice leadership which is concept referring to democratic, inclusive and innovative practice that transforms social structures and influence all role-players to promote justice and equity in schools (Foster, 1989). Effective education leaders will be those that are able to think inclusively and democratically whilst redressing 
injustices (Wang, 2018). However, social justice in schools need the involvement of all. Hence, Ezzani (2020) argues that social justice leaders should coach teachers and advance practices that underscore respect and dignity and these are crucial in collaboration strategies to social justice leadership. Social justice approaches are an antidote to how society treats the marginalised people and their philosophies. Socially just leadership is critical to the building of socially just schools devoid of glaring injustices based on inequities

Thinking, Unthinking and Rethinking are crucial in selfreflection as leaders seek to understand who they are as leaders and challenge inequalities in school leadership in Africa. By its nature the TURNS model's self-reflection leads not only to knowing about oneself but also about understanding the diversity of the organisation.

Santamaria (2014) argues about the need for diversity to inspire transformation and improvement of organisations. Education leadership should support social justice and educational equity. Selfreflective leaders are likely to glean from progressive decolonisation models that seek to coalesce Western and indigenous models of leadership. The bottom line is that educational leaders should accommodate all their followers and this begins with understanding oneself. "Positive identity traits associated with ethnic, cultural, linguistic, and gender diversity....are manifested in terms of leadership for social justice and education equity" (Santamaria, 2014, p. 383). Whilst TURNS cannot only be applied to decolonisation it is posited as a critical tool to utilise in self-reflection and decolonised leadership. In instilling leadership that seeks to transform institutions and empower all it needs conscious efforts to be applied in nurturing certain skills and reinforce several practices. 
Decolonisation of leadership would enable leaders to add their experiences to their practice and experiment their marginalised knowledges in order to be culturally responsive (Santamaria and Santamaria, 2015). The practice of decolonised leadership ensures that the subaltern knowledge shares the centre with other knowledges. Decolonial struggles should begin with the preparation of the people, enabling them to be ready to discard colonialism and Eurocentrism. In embracing epistemic freedom and in preparing future African school leaders, we all need to think about conscious or intentional transformative trajectories. There are several norms in society wherein some groups have been oppressed and these manifest themselves in leadership as well. Systemic injustice marginalises many people as it creates epistemic violence and colonial denigration. Decolonisation should be able to address what Young (1990) refers to as the five faces of oppression; exploitation, marginalisation, powerlessness, cultural imperialism and violence. Oppressive institutions cannot be centres of social justice and just leadership. In an atmosphere of oppression, leadership cannot speak of effective leadership and worthy followership.

Khalifa et al. (2019) point out that the colonial origins of formal education institutions have an immense impact on educational leadership. These authors state that Westernised Eurocentric schooling serves as a tool of imperialism, colonisation and control in the education of indigenous peoples. They argue for an Indigenous Decolonising School Leadership framework that seeks to decolonise school leadership and build on indigenous people's "ancestral assets and knowledges" Khalifa et al. (2019, p. 585).

All progressive leaders would want to address the colonial administrative practices as they seek to accommodate indigenous and 
community-based practices. Western hegemonies have been shown to be dangerous and misleading. Based on colonial notions of domination, they marginalise other knowledges and debar Africans from expressing their own knowledges as central. For this reason, Ndlovu-Gatsheni (2018) affirms of the need to deprovincialise Europe, as Africa is being decolonised. This is-needed to dispel colonialism as Africa's knowledge is brought to the centre.

In South Africa, apartheid management in schools was always hierarchical in nature and school managers were never expected to be creative. The system of Fundamental Pedagogics stressed the importance of obeying authority at all times. This emphasised the authority of the inspectors and the obedience of teachers (Steyn et al., 1988). Obedience was part of pedagogic authority - a child (learner) should be obedient to the responsible adult (a teacher) who in turn had to be obedient and loyal to the inspectors. "Freedom for responsibility means to obey the authority of norms" (Steyn et al., 1988, p. 218). Apartheid schools had a fixed set of rules and these influenced a number of punishments for breaking these rules for the learners and their teachers and the leadership of the teachers (Christie, 1988). Khalifa et al. (2019, p. 603) state,

...colonisers claimed that to de-barbarise, Christianise, and civilise the indigenous people would be to humanise them. That notwithstanding, a more likely goal for colonisers was to use schools to develop indigenous workers and managers who would ensure that human and natural resources of the colonised lands would flow exclusively toward the colonisers and European lands.

As a result, many educational leaders unconsciously promoted imperial practices through their styles of leadership. Their practice reflected colonialism and oppressive styles. 
Lopez and Rugano (2018) argue that school leadership preparation should reflect the contexts and experiences of the African educators rather than merely adopting exclusive experiences of preparation from the Global North. The experiences of principals in the Advanced Certificate in Education (ACE) - School Management and Leadership (ACE-SML) programme between 2007 and 2011 demonstrated the critical nature of local South African contexts when preparing school leaders and managers (Bush et al., 2009; Bush et al., 2011).

The introduction of the ACE-SML Programme for school managers in 2007 was an initiative to formally prepare school managers for positions of leadership. Hitherto, principals and other management team members were appointed based on their classroom performance. The ACE-SML Programme did not necessarily focus on the decolonisation of leadership. However, the results demonstrated the need to look at various ways of improving leadership and this includes parental involvement and the utilisation of vision (Bush, Kiggundu \& Moorosi, 2011; Msila, 2011). Additionally, the results showed the need to methodically and thoroughly prepare school leaders for successful school leadership. This also means that preparing today's leaders needs management curricula that would oppose the colonial legacy in leadership preparation programmes. The management programmes should address the epistemic violence in management programmes. Rugguman (2016) contends that the curriculum of management studies in South Africa extends epistemic violence, which refers to the violence of knowledge production. The preparation of a new leadership corps is critical for institutions so that they avoid the repetition of epistemic violence. New values that support social justice and cognitive justice should be part of decolonial management programmes. 


\section{Rethinking Leadership: Why Values Matter?}

Leaders in educational institutions need principled leadership accompanied by authentic values. It is my contention that when inspired by the TURNS model, Principled leaders who are intent on decolonisation will, after rethinking thinking, nurture and solidify appropriate values that will define their practice. Glynn and Jamerson (2006) point out that principled leadership starts by recognising the ethical dimensions of leadership actions, followed by prioritising one's values and then aligning them with those of the organisation. This process forms part of thinking, unthinking and rethinking leadership through the search for principled leadership that would lead to selfreflection.

Glynn and Jamerson (2006) point out that principled leadership encompasses leading courageously with humanistic values, which include integrity, fairness, respect and humility. Being courageous, fair, humble and honest are also values linked to these humanistic values of principled leadership. Boon (2001) writes about the need for the interactive nature in the Ubuntu worldview but also emphasises the need for the organisation to create values. Boon (2001, p. 84) states that principles "are fundamental world truths and do not change with time. The same things appear in every major philosophy and religion in the world. They are universal truths that reflect our humanity". Values cannot be created by leaders alone, hence leaders should build communities that should be shared and involve all the members. These can be solidified within the fabric of an institution where leaders can nurture their practice utilising these values.

Broodryk (2006) claims that values are related to norms and social rules. Leaders will know which values will enhance the effective operations in the organisation. Broodryk (2006) also affirms that there 
are core values in the Ubuntu worldview that form the basis of thriving organisations. Humanness, caring, sharing, respect and compassion are pivotal values for successful organisations. Msila (2015) maintains that Ubuntu-inspired workplaces focus on dependability, teamwork, interconnectedness, caring, collective vision, performance and loyalty. Mbigi (1997) has also found that there are five key values for Ubuntu and these are survival, solidarity, spirit, compassion, respect and dignity. Mbigi perceives these as originating from the African cultures.

Yet although Ubuntu has all these positive qualities when it comes to women leaders it can be dubious due to the influence of patriarchy and traditional hierachy. Patriarchy is one of the potent ills in society today and it is real and needs to be opposed as women fight for social justice and meaningful leadership. The gender stereotyping including patriarchy imposed by the society is opposed by the Ubuntu worldview. Understating models of rethinking leadership is critical in ensuring that leaders are able to know their voice as they express their leadership practices. Ngunjiri (2016) argues that there needs to be more women research in Africa. In patriarchal environments we cannot assume that theories that apply to women also apply to men the same way. Yet Ngunjiri (2016) and Viviers \& Mzondi (2016) argue that women are most likely to use Ubuntu because it is linked to motherhood, participative and servant leadership.

However, Manyonganise (2015) studied Ubuntu among Zimbwabwean women and found that even in Ubuntu, the rules are set by men who tend to avoid focussing on women subordination. The men may patronise women as nurturers, as purveyors of love and compassion but still downplay their humanity. Manyonganise posits that although Ubuntu does have liberatory qualities it has much oppressive elements that support patriarchy. She points out that 
Ubuntu can sometimes be gender insensitive. Some cultural practises dehumanise women in the name of Ubuntu and tradition and customs. Within Ubuntu men are expected to be land owners, breadwinners, providers and it is within these concerns that Ubuntu needs to be examined when it comes to gender relations (Manyonganise, 2015). Isike and Uzodike (2011) opine that negative masculinities in the African continent have made women victims of various forms of abuse. These authors also add that the positive human factors which defined womanhood before were corrupted by colonial interruption "of Africa's socio-cultural existence leading to the marginalisation, tokenisation and de-feminisation of women" (Isike \& Uzodike, 2011). For women rethinking leadership have to think of two aspects; on the one hand is their personal development whilst on the other they need to eschew or confront the patriarchal society's notion of women leadership. Despite the patriarchal society, women need to embrace certain values including Ubuntu to enhance their leadership. Rethinking should enable them ward off the negative effects of patriarchy which taints Ubuntu and other critical values. Patriarchy as well as the hierarchy enforced by tradition upon women reflect the blacknisation that Wa Thiong'o highlights above.

Several values as highlighted are pertinent in engendering leadership for social justice. Schools all over the world are under pressure to promote innovation and enhance a school culture that would lead to learner achievement. Leaders need effective strategies for leading successful schools. Harris and Johnston (2010) state that values-based leadership is pivotal in sustaining school transformation and improvement. As leaders rethink their leadership strategies, they need to find their rhythm and voice as they share their vision and goals with the followers Yet Ubuntu will only be successful when leaders are 
able to lead with the intention of decolonising the institutions. In finding their voices, decolonised leaders will be able to:

Model the way - clarifying their personal values:

Inspire a shared vison - leader need to share their aspirations in a meaningful manner;

Challenge the process - as they seek new methods of innovation leader will have to challenge the status quo.

Enable others to act - Leaders promote cooperation and build trust among the followers.

Encourage the heart - Effective leaders will accept individual excellence as they create a spirit of community (Kouzes and Posner in Harris and Johnston, 2010).

Incidentally, the five concepts above are at the centre of Ubuntu leadership. Ubuntu seeks to bring the African values into leadership and these include trust, solidarity, cooperation, commitment and communal values.

\section{Conclusion}

The TURNS leadership empowerment model explicated in this article is an example of how leaders can use self-reflection to enhance their leadership practice. In the face of a dynamic organisation, effective leaders will always seek to reinvigorate their practice whilst improving their institutions. Rejuvenating leadership in African institutions means using various philosophies including decolonisation. o leaders can reimagine institutional changes without understanding themselves as well as the contexts in which they lead. Ladkin (2010) states that rethinking leadership presents a reconceptualisation of leadership as "a contextually embedded, physically embodied phenomenon." Leaders will not realise this rethinking without constant self-reflection evident in models such as 
TURNS. Progressive leadership forces leaders to be lifelong learners who learn at all times. Leaders today work in complex organisations that compel them to analyse their leadership practice all the time. Leaders who look for successes only in their institutions will fail; it is leaders who search themselves who will be successful in leading organisations (Kotter, 1995). The TURNS model is about the recreation of institutions through introspection and self-criticism. Effective leadership starts with understanding oneself before one can inspire others and build the institution.

Beyond the era of decolonisation, organisations in Africa will need leadership styles based on the ecologies of knowledges. The calls for transformation of institutions and for leaders who are visionary and who would take it upon themselves to bring about stainable organisations based on social justice principles. The Western models such as shared leadership, servant leadership, and conscious leadership will be invaluable for organisations when used in combination with indigenous leadership strategies that reflect the African values. The TURNS model is also about transformation of organisations through thoughtful leadership. The entire TURNS cycle from Thinking to Solidifying is a quest for best practices. Leading in decolonised environments requires leaders who will understand the need for approaches that accommodate diversity, relevance and new values that would sustain today's organisations.

Attuned leaders will be courageous leaders who have a vision to lead effective organisations. Courageous leaders would be able to define their objectives in a fast-changing environment and seek to try new strategies that decentre Western epistemologies. New leadership would start with the decolonisation of the mind. Leaders with no right consciousness will not be able to lead. Infusing African/indigenous 
leadership in today's institutions demands new leaders with a new critical consciousness. Finally, the process of thinking and rethinking leadership will build conscious, courageous and intentional leaders who use their influence to create other leaders as well.

\section{References}

Afegbua, S.I. \& Adejuwon, K.H. (2012). The challenges of leadership and governance in Africa. International Journal of Academic Research in Business and Social Sciences, 2(9), 141-157.

Bennett, B. (2003). Job rotation: Its role in promoting learning in organisations. Development and Learning in Organisations. 17(4), 7-9.

Boon, M. (2001). The African way: The power of interactive leadership. Cape Town: Zebra.

Broodryk, J. (2006). Ubuntu: Life-coping skills from Africa. Randburg: Knowledge Resources.

Bush, T., Duku, N., Glover, D., Kiggundu, E., Kola, S., Msila, V. \& Moorosi, P. (2009). External evaluation research report of the Advanced Certificate in Education: School leadership and management. Pretoria: Department of Education.

Bush, T., Kiggundu, E. \& Moorosi, P. (2011). Preparing new principals in South Africa: The ACE: School Leadership Programme. South African Journal of Education, 31, 31-43.

Bush, T., Duku, N., Glover, D., Kiggundu, E., Kola, S., Msila, V. \& Moorosi, P. (2012). The impact of the National Advanced Certificate in Education: Programme on school and learners' outcomes (School Leadership and Management Research Report). Pretoria: Department of Education.

Christie, P. (1988). The right to learn: The struggle for education in South Africa. Braamfontein: Sached/Ravan. 
Davies, B. (2010). Rethinking educational leadership: From improvement to transformation. International Journal of Educational Management, 24(4), 371-371.

De Padua, A. \& Rabbitskin, N. (2017). Working with indigenous leadership and indigenous environments. In J. Wagner (ed.). Leadership Influencing Change in Nursing, (p. 52-72). Regina: University of Regina Press.

Dethmer, J., Chapman, D. \& Klemp, K. (n.d.). The 15 commitments of conscious leadership: A new paradigm for sustainable success. New York: Conscious Leadership Group.

Elonga Mboyo, J.P. (2019). Reimagining Ubuntu in schools: A perspective from two primary school leaders in the Democratic Republic of Congo, Educational Management Administration $\mathcal{E}$ Leadership, 47(2), 206-223.

Ezzani, M. (2020). A principal's approach to leadership for social justice: Advancing reflective and anti-oppressive practices. Journal of School Leadership, https://journals.sagepub.com/doi/full/10.1177/10526846209083 47

Foster, W. (1989). Toward a critical practice of educational leadership. In J. Smith (Ed.), Critical perspectives on educational leadership (p. 39-62). London, England: Falmer Press.

Freire, P. (1970). Pedagogy of the oppressed. New York: Continuum.

Glynn, M. \& Jamerson, H. (2006). Principled leadership: A framework for action. In E.D. Hess \& K.S. Cameron (eds.). Leading values: Positivity, virtue, and high performance, (p. 151-171).Cambridge: Cambridge University Press.

Hallinger, P. (2018). Bringing context out of the shadows of leadership. Education, Management, Administration \& Leadership, 46(1), 5-24.

Harris, M. \& Johnston, M.A. (2010). Values-based leadership: At the heart of sustaining school reform and improvement. In S.G. 
Huber (ed.). School Leadership - International Perspectives, (p. 145158). Dordrecht: Springer.

Igue, J. (2010). A new generation of leaders in Africa: What issues do they face? International Development Policy, 1, 115-133.

Isike, C. \& Uzodike, U.O. (2011). Towards an indigenous model of conflict resolution: Reinventing women's roles as traditional peace-builders in neo-colonial Africa. African Journal of Conflict Resolution, 11(2), 32-58.

AJCR, 2011 (2). Retrieved from https://www.accord.org.za/ajcrissues/towards-an-indigenous-model-of-conflict-resolution/

Khalifa, M.A., Khalil, D., Marsh, T.E.J. \& Halloran, C. (2019). Toward an indigenous, decolonizing school leadership: A literature review. Educational Administration Quarterly, 55(4), 571-614.

Khoza, R. (2012). Attuned leadership: African humanism as compass. Cape Town: Penguin.

Kotter, J. (1995). Leading change: Why transformation efforts fail. Harvard Business Review, 73(2), 59-68.

Ladkin, D. (2010). Rethinking leadership: A new look at old leadership questions. Cheltenham: Elgar.

Laplanche, J. \& Pontalis, J. (1973). The language of psychoanalysis. New York: Hogarth Press.

Lopez, A.E. \& Rugano, P. (2018). Educational leadership in postcolonial contexts: What can we learn from the experiences of three female principals in Kenyan schools? Education Sciences, 8(99), https://doi.org/10.3390/educsci8030099

Macedo, D. (1999). Preface - Decolonising indigenous knowledge. In L.M. Semali \& J.L.

Manyonganise, M. (2015). Oppressive and Liberative: A Zimbabwean woman's reflections on Ubuntu. Verbum et Ecclesia, 36(2) DOI: https://doi.org/10.4102/ve.v36i2.1438 
Mazrui, A. (2000). The African renaissance: A triple legacy of skills, values and gender. A Publication of CBAAC (occasional monographs No.9)

Mbigi, L. (1997). Ubuntu: The African dream management. Randburg: Knowledge Resources.

Mbigi, L. (2004). The spirit of African leadership. Randburg: Knowledge Resources.

Msila, V. (2008). Ubuntu and school leadership. Journal of Education, 44, 67-84.

Msila, V. (2015). Ubuntu shaping the current workplace with (African) wisdom. Randburg: Knowledge Resources.

Msila, V. (2020). Leadership Training Workshop for school leaders: The TURNS model. Siyomba Leadership Projects. Pretoria: Siyomba Trainers.

Murphy, J., Neumerski, C.M., Goldring, E., Grissom, J. \& Porter, A. (2016). Bottling fog? The quest for instructional management. Cambridge Journal of Education, 46 (4), 455-471.

Naidoo, P. (2019). Perceptions of teachers and school management teams of the leadership roles of public school principals. South African Journal of Education, 39(2), 1-14.

Ndlovu-Gatsheni, S.J. (2018). Epistemic freedom in Africa: Deprovincialization and decolonization. London: Routledge.

Newman, L. (2012). Rethinking thinking through positive leadership. Retreived from https://www.iedp.com/articles/rethinkingthinking-through-positive-leadership/

Ngunjiri, F.W. (2016). "I Am Because We Are": Exploring women's leadership under Ubuntu worldview. Advances in Developing Human Resources, 18(2): 223-242.

Nyerere, J.K. (1968). Ujamaa. English Ujamaa--Essays on socialism. Dar es Salaam, Oxford University Press. 
Nyerere, J.K. (1970). Freedom and Unity/Uhuru Na Umoja. Dar es Salaam: Oxford University Press.

Odora Hoppers, C.A. (2009). Engaging critically with tradition, culture and patriarchy through lifelong learning: What would Julius Nyerere say? Sixth Annual Julius Nyerere Memorial Lecture. [Online] Available

http://uir.unisa.ac.za/bitstream/handle/10500/22759/UWC\%20

6TH\%20JULIUS\%20NYERERE\%20Odora\%20Hopper\%27s\%2 0Paper.pdf

Odora Hoppers, C. \& Richards, H. (2011). Rethinking thinking: Modernity's 'other' and the transformation of the university. Pretoria: University of South Africa Press.

Okeke, J.C. (2018). The Impact of colonisation and authentic leadership on Africa: Nigeria - A case study. (Unpublished PhD Dissertation). Regent University.

Rugguman, S.D. (2016). Decolonising management studies: A love story. Acta Comercii, 16(2), 103-138.

Saffari, S. (2016) Can the subaltern be heard? Knowledge production, representation, and responsibility in international development. Transcience, 7(1), 36-46.

Santamaria, L.J. (2014). Critical change for the greater good: Multicultural perceptions in educational leadership toward social justice and equity. Educational Administration Quarterly, 50(3), 347-391.

Santamaria, L.M.J. (2016). Theories of educational leadership. Oxford: Oxford University Press.

Santamaria, L.J. \& Santamaria, A.P. (2015). Counteracting educational injustice with applied critical leadership: Culturally responsive practices promoting sustainable change. International Journal of Multicultural Education, 17(1), 22- 41.

Senge, P. (1995). Leading learning organisations. Retrieved from 
https://infed.org/mobi/peter-senge-and-the-learningorganization/

Stewart, J. \& Warn, J. (2017). Between two worlds: Indigenous leaders exercising influence and working across boundaries. Australian Journal of Public Administration, 76(1), 3-17.

Steyn, P.D.G., Bisschoff, T.C., Behr, A.L. \& Vos, A. J. (1988). Education 3: The philosophical foundations of education. Cape Town: Maskew Miller Longman.

Toffler, A. (1970). Future shock. New York: Random House.

USB-ED. (2018). Six of the African continent's biggest leadership challenges Retrieved from https://usb-ed.com/blog/six-of-theafrican-continents-biggest-leadership-challenges-2018/

Vaughan, M. (2013). The thinking effect: Rethinking thinking to create great leaders and the new worker. London: Nicholas Brealey Publishing.

Vermey, C.M. (2014). What is 'Conscious Leadership' and why it is crucial for successful businesses? Retrieved from https://www.bizjournals.com/philadelphia/blog/guestcomment/2014/08/what-is-conscious-leadership-and-why-isit-crucial.html

Viviers, H. \& Mzondi, A.M.M. (2016). The end of essentialist gods and Ubuntu: a feminist critical investigation. Pharos Journal of Theology, 97, 1-17.

Wafawarova, R. (2015). Africa's leadership failure. Retrieved from http://www.herald.co.zw/africas-leadership-failure/

Wai, D.M. (1997). Mazruiphilia, Mazruiphobia: Democracy. governance and development. In O.H. Kokole (ed.). The Global African: A Portrait of Ali A. Mazrui, (p. 37-76). Trenton, New Jersey: Africa World Press.

Wang, F. (2018). Social justice leadership theory and practice: A case of Ontario. Educational Administration Quarterly, 54(3), 470-498. 
Wa Thiong'o, N. (1987). Decolonising the mind: The politics of language in African literature. London: James Currey.

Wa Thiong'o, N. (1993). Moving the centre: The struggle for cultural freedom. London: Heinemann.

Wa Thiong'o, N. (2007). Wizard of the crow. Lagos: Farafina.

Wa Thiong'o, N. (2012). Globalectics: Theory and the politics of knowing. New York: Columbia University Press.

Young, I.M. (1990). Justice and the politics of difference. Princeton: Princeton University Press.

\section{About the author:}

Dr. Vuyisile Msila is a former head of the University of South Africa's (Unisa) Institute for African Renaissance. He is now a researcher and professor at the Thabo Mbeki African School of Public and International Affairs based at Unisa. His research interests include Education Leadership as well as Africanisation and Decolonisation of education.

Email: msivuy@gmail.com 